\title{
PUBLIC VALUE THROUGH TECHNOLOGIES DEVELOPED WITH OPEN GOVERNMENT DATA: THE LOVE SERENADE OPERATION CASE
}

\author{
EDUARDO D. COUTINHO ${ }^{1}$ \\ (iD) https://orcid.org/0000-0002-5551-942X \\ ANGILBERTO S. FREITAS \\ (ID) https://orcid.org/0000-0002-9329-1745
}

To cite this paper: Coutinho, E. D., \& Freitas, A. S. (2021). Public value through technologies developed with open government data: The Love Serenade Operation case. Revista de Administração Mackenzie, 22 (6), 1-26. doi:10.1590/1678-6971/eRAMD210079

Submission: Mar. 21, 2021. Aceite: Sept. 8, 2021.

1 University of Grande Rio (Unigranrio), Duque de Caxias, RJ, Brazil.
2 West Zone University Center (Uezo), Rio de Janeiro, RJ, Brazil.

\section{(c) $\mathrm{BY}$

This paper may be copied, distributed, displayed, transmitted or adapted for any purpose, even commercially, if provided, in a clear and explicit way, the name of the journal, the edition, the year and the pages on which the paper was originally published, but not suggesting that RAM endorses paper reuse. This licensing term should be made explicit in cases of reuse or distribution to third parties.

Este artigo pode ser copiado, distribuído, exibido, transmitido ou adaptado para qualquer fim, mesmo que comercial, desde que citados, de forma clara e explícita, o nome da revista, a edição, o ano e as páginas nas quais o artigo foi publicado originalmente, mas sem sugerir que a RAM endosse a reutilização do artigo. Esse termo de licenciamento deve ser explicitado para os casos de reutilização ou distribuição para terceiros. 


\section{ABSTRACT}

Purpose: To understand the public value that the website Operação Serenata de Amor [Love Serenade Operation], based on open government data, can generate for society.

Originality/value: Researchers are investigating public value generation through digitally transformed public services, i.e., public value directly generated by the government. However, the literature needs a better understanding of this phenomenon through digital technologies, based on open public data, developed by non-governmental actors, such as the Operação Serenata de Amor website.

Design/methodology/approach: The study adopted a qualitative approach to understand and describe the public value generated by Operação Serenata de Amor. The data were collected through citizen comments about the website's initiatives on social media and in articles published on the internet. The data were analyzed through content analysis.

Findings: The Operação Serenata de Amor generated public value by doing, facilitating, and stimulating social control. It was also identified that the site added value to society by increasing citizens' ability to exercise social control. However, this work was limited to analyzing data collected on the internet. In future studies, researchers may collect data through interviews with citizens to understand, with more details, the public value generated by the website.

\section{KEYWORDS}

Government's digital transformation. Open government. Open public data. Public value. Social control. 


\section{INTRODUCTION}

In several countries, the digital transformation of governments has shown results that demonstrate a more efficient public performance, integrated, accurate, flexible, and transparent (Goede, 2019; Mergel, Edelmann, $\&$ Haug, 2019). In addition, the advancement of digital transformation and the opening of public data has boosted the interoperability of data between public organizations and actors outside governments, creating an ecosystem conducive to the development of digital services and technologies capable of adding value to society (Cordella \& Paletti, 2019).

In some developed countries, such as the United States and the United Kingdom, the opening and sharing of public data between public organizations and external innovators have advanced to the point of adopting the concept of government as a platform - government as a platform (GaaP) (Brown, Fishenden, Thompson, \& Venters, 2017). The GaaP model understands that software and data in public platforms must be open to third parties, such as citizens and private organizations, to complement and develop services and technologies capable of generating value for society (Brown et al., 2017; Cordella \& Paletti, 2019).

One of the main technological supports for the adoption of the GaaP Model is the open government data platform (OGDP) (Brown et al., 2017), since this kind of innovation allows external users to public administration use government data to develop digital technologies and services, such as the British transport application Citymapper, developed by a private organization with open public data, to provide a service of public value (Bonina $\&$ Eaton, 2020).

Worldwide, the GaaP model stimulates the development of several other digital technologies based on open public data. These technologies have contributed to the generation of public value, either through the improvement and development of services for society (Bonina \& Eaton, 2020) or through the expansion of transparency of government actions, democratic participation, and engagement of citizens in social control (Cordella \& Paletti, 2019).

In Brazil, although the GaaP model is not yet a reality for legal and institutional reasons (Brazil, 2021a), the adoption of a portal for sharing open government data between public and private actors has occurred since 2011, when the Brazilian Portal of Open Data (Portal Brasileiro de Dados Abertos PBDA) was created (Brazil, 2021b). 
The creation of the PBDA was a technological innovation to make the Brazilian government more transparent and especially more open to external actors (Brazil, 2021b), contributing to the strengthening of a new civic and administrative paradigm of the State, the open government (Michener, Contreras, \& Niskier, 2018).

Brazil, like many countries, followed the global trend of adopting the concept of open government (Salomão, 2017), which can be understood as the intensive use of digital technologies to facilitate, encourage and expand government transparency, the opening, and sharing of public data, access to public information and participation and social control, which requires many initiatives by the government and actors outside the public administration, as well as a legal framework that supports and regulates these initiatives (Nam, 2012; Tai, 2021). In Brazil, the Access to Information Law - Law no. 12.527/2011 (Salomão, 2017) and the General Data Protection Law - Law no. 13.709/2018, as amended by Law no. $13.853 / 2019$ (Brazil, 2021c), are examples of legal norms that sought to contribute to the advancement of open government.

The PBDA, one of the technological innovations that contributed for strengthening the concept of open government in Brazil, had, on March 6, 2021, 9,878 data sets made available by 193 public organizations (Brazil, 2021d, 2021e). PBDA has been collaborating to the development of technologies that help in social control, as the data made available on the portal allowed actors outside the government to create digital technologies to facilitate and encourage the monitoring and inspection of public accounts and acts (Brazil, 2021f, 2021g), which is a potential factor in generating public value. As a rule, the engagement of Brazilian citizens in social control is still quite low (Andrade \& Andrade, 2019; Sabioni, Ferreira, Braga, \& Almeida, 2016).

Among these digital technologies developed with open public data to assist in social control is the Operação Serenata de Amor [Love Serenade Operation] website, the result of a technological project that sought to use artificial intelligence (AI) to help in social control through the inspection of public accounts of senators and congressmen (Brazil, 2021h).

Considering that the main objective of the PBDA is to encourage the use of open public data for the generation of technologies and services that add value to society (Brazil, 2021f) and that initiatives that seek to expand social control present themselves as potential generators of public value due to the low engagement of citizens in this democratic right, this study raises the question: 
- How does the site Operation Serenata de Amor, based on open government data, can generate value for society?

To answer this question, the objective is to understand the public value that the website Operação Serenata de Amor can create for society.

\section{LITERATURE REVIEW}

This section is divided into four subsections. The first subsection addresses the issues of government's digital transformation and government as a platform. The next subsection defines and presents the specificities of open government data platforms, considering them as innovation platforms. The third subsection addresses the concept of public value and how this phenomenon can happen through digital services and technologies developed based on open public data. The last subsection presents the concept of social control and its application in a digital environment.

\subsection{Government's digital transformation and government as a platform}

The concept of government's digital transformation must not be confused only with the digitization of production processes and provision of public services since this is a more complex phenomenon. The migration of processes and services from the physical environment to the virtual environment is part of the digital transformation process. However, this alone is insufficient to set the digital transformation of a government (Mergel et al., 2019).

It can be inferred that the governments' digital transformation is a paradigm shift in their institutional structures and in their governmental role model (Le, Kim, Park, Park, \& Oh, 2018). It is an organizational change strongly mediated by digital technologies, making the government more agile, flexible, integrated, cooperative, efficient, transparent, and centered in the real needs of society (Curtis, 2019; Mergel et al., 2019).

Numerous benefits of government digital transformation can be listed and cover internal and external government environments, such as 1. digitization and automation of production processes and provision of public services; 2 . unified access to digital public services; 3. interoperability and data reuse; 4 . possibility of immediate and multiple access to documents; 
and 5. internal processes and sharing of digital infrastructures, among others (Nielsen \& Jordanoski, 2020; Scupola, 2018).

The research literature on the subject shows evidence of the government's digital transformation benefits for the population. For example, Datta, Walker, and Amarilli (2020) found that the Italian government has added value to society by developing the digital platform PagoPA, which made it possible, in a single digital channel, to carry out payments of fees and taxes to the federal government. User ratings showed that the platform made the payment process faster and easier, generated more payment options, and proved to be friendlier, safer, and less susceptible to technical errors. Senyo, Effah, and Osabutey (2021) found that, after digitizing a public port in Ghana, services became simpler, more agile, integrated, and precise, requiring less effort from users to have their demands met.

Moreover, the government's digital transformation is critical to the adoption of the government model as a platform (GaaP), considering that, for this type of model to be implemented, it is necessary: a high level of digitization; and the integration among public organizations in such a way that it provides the opening of accurate, secure, useful and easy-to-use public data (Brown et al., 2017; Cordella \& Paletti, 2019).

A central aspect of the GaaP is the possibility of a wide availability and interoperability of data and systems between public organizations and actors outside the government. This is because the main objective of adopting a GaaP model is to enable, through the opening of public data and systems, citizens and private organizations to develop and improve services that the government was unable to devise or did not have the resources to implement (O'Reilly, 2011), making these platforms a fundamental technological support to the successful adoption of a GaaP model (Brown et al., 2017; Cordella \& Paletti, 2019).

\subsection{Open government data platforms}

Before addressing the specificities of the open government data platforms, it is important to understand what a digital platform is and how they are sorted (Bonina \& Eaton, 2020). At this point, the literature does not provide a homogeneous definition for the term "digital platform", which is explained mainly by the fact that this digital technology is studied by researchers working in very different fields of knowledge. However, in a broad sense, it is possible to consider one definition for a digital platform based purely on technical artifacts and another one characterized by socio- 
technical elements (De Reuver, Sørensen, \& Basole, 2018; Koskinen, Bonina, \& Eaton, 2019).

In light of the technical aspect, a digital platform can be defined as an ecosystem that contains a codebase that can be extended to modules developed by third parties (Hukal, Henfridsson, Shaikh, \& Parker, 2020; Tiwana, 2014, 2015, 2018). According to the sociotechnical aspect, digital platforms can be characterized by the association of technical elements (software and hardware) with organizational processes and structures (De Reuver et al., 2018).

Although the concept of a digital platform is strongly sensitive to the specificities and interests of each area of knowledge, the vast majority of digital platforms share three basic characteristics: technological mediation, interactivity between different groups of users, and the possibility of simultaneous activities by each group of users (Koskinen et al., 2019). Furthermore, it is possible to classify digital platforms into three categories: 1. transaction platforms; 2 . innovation platforms; and 3. integration platforms (Koskinen et al., 2019).

Digital transaction platforms aim to facilitate relationships between different interested parties, adding value to their users by mitigating frictions and transaction costs that occur in a physical environment. Several types of digital transaction platforms are classified according to their functionalities (Koskinen et al., 2019). For example, shared economy platforms provide a collaborative network between users, such as Airbnb, which allows its members to rent and offer real estate among them (Leoni \& Parker, 2019; Petrini, Freitas, \& Silveira, 2017). Another type of transactional digital platform is the commercial platform, also known as a multi-sided platform, such as Alibaba and eBay, which enable commercial relationships between sellers and buyers (Hänninen, Smedlund, \& Mitronen, 2018). Although there are transactional platforms with different functionalities, they all have the common objective of adding value to two or more groups of users (Täuscher \& Laudien, 2018).

Innovation platforms, on the other hand, act as technological bases for the development of modules that add value. iOS, Android, Windows, and Linux operating systems are examples of this type of digital platform, as they share digital infrastructure for the development of various software and applications, which are also known as platform modules (Croitor \& Benlian, 2019; Tiwana, 2014, 2015).

In addition to innovation and transaction platforms, there are integration platforms, which work like transaction platforms; however, with typical 
features of innovation platforms. They have a technological structure that enables their users to create complementary services. A good example of an integration platform is Facebook, which aims to connect people on social networks and, at the same time, allows its users, through Facebook for Developers, to develop modules to be integrated into the platform (Koskinen et al., 2019).

Figure 2.2.1 shows the types and examples of digital platforms, as well as their definitions.

(Figure 2.2.1)

TYPES OF DIGITAL PLATFORM

\begin{tabular}{|c|c|c|}
\hline Type of digital platform & Definition & Examples \\
\hline Transaction platform & $\begin{array}{l}\text { Platforms that provide different types of } \\
\text { transactions among users, such as social, } \\
\text { commercial, employment, and educational } \\
\text { (Koskinen et al, 2019). }\end{array}$ & Alibaba, eBay e Uber. \\
\hline Innovation platform & $\begin{array}{l}\text { Platforms that work as a technological basis } \\
\text { for the development of modules that add } \\
\text { value to it (De Reuver et al., 2018). }\end{array}$ & $\begin{array}{l}\text { iOS, Android, Windows, } \\
\text { and Google Chrome. }\end{array}$ \\
\hline Integration platform & $\begin{array}{l}\text { Transaction platforms with a technological } \\
\text { structure that enables the development of } \\
\text { complementary services by users (Koskinen } \\
\text { et al., 2019). }\end{array}$ & $\begin{array}{l}\text { Facebook for } \\
\text { Developers and } \\
\text { Twitter Developer. }\end{array}$ \\
\hline
\end{tabular}

Source: Elaborated by the authors

Open government data platforms (OGDP) are classified as innovation platforms, and instead of functioning as a technological framework for developing modules peripherals (applications and software), they operate as a central base for data interoperability between government and external actors to the public administration, using the public data sets (OGDP modules) to provide services to society (Bonina \& Eaton, 2020; Danneels, Viaene, \& Bergh, 2017).

The OGDP is administered by a government, which is the platform owner. Users can be public bodies, citizens, and private organizations. The government manages the platform and seeks to encourage public organizations to make datasets available to be used among them and by actors outside the government (Bonina \& Eaton, 2020).

The architectural focus of an OGDP is a central framework that allows the coupling of modules as a dataset for government and third-party 
developers, who create services for a society based on these open public datasets (Bonina \& Eaton, 2020).

The government, owner of the platform, seeks to encourage the provision of datasets by public bodies, as well as the use of these data for the development of services to society, creating an ecosystem consisting of government, public bodies, third-party innovators and society, which is represented by the end-users of all services created with open public data (Bonina \& Eaton, 2020; Danneels et al., 2017), as shown in Figure 2.2.2.

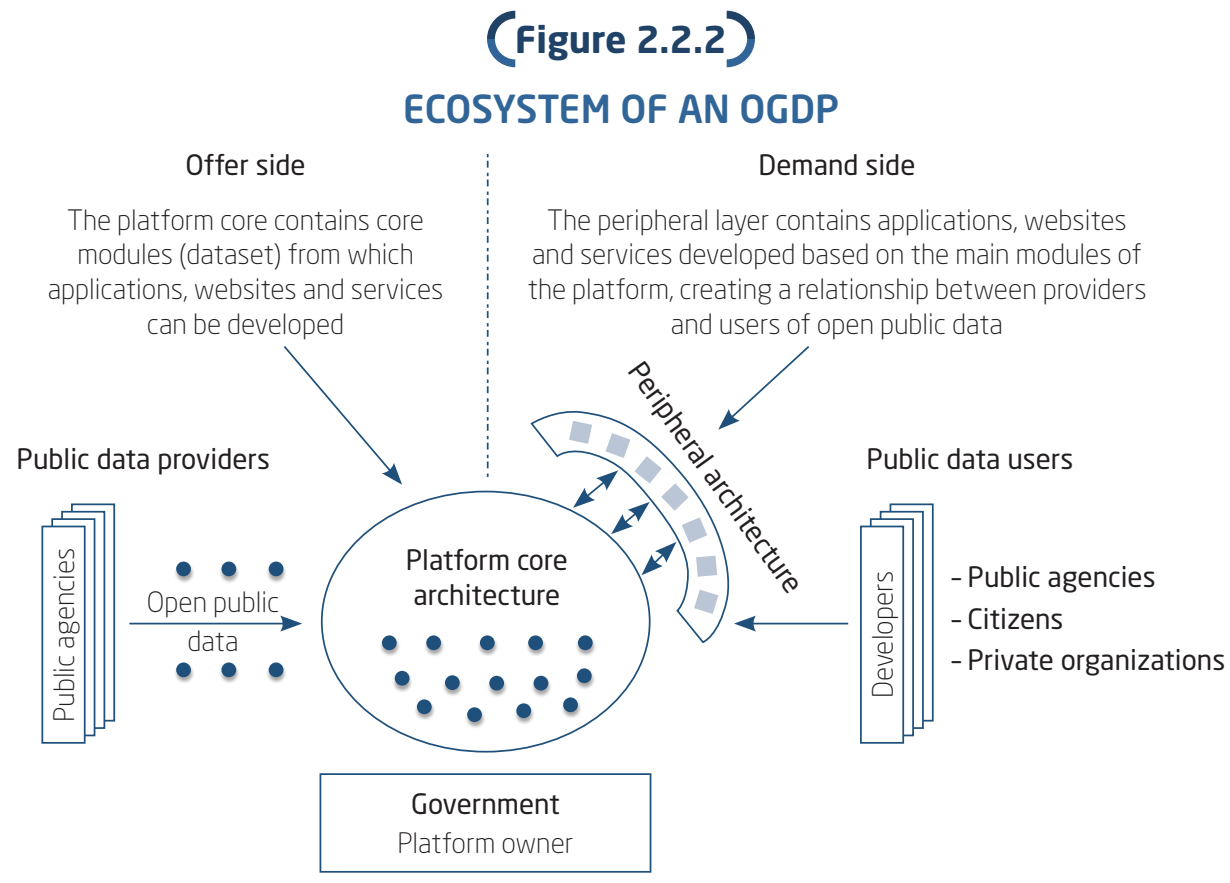

Source: Elaborated by the authors based on Bonina and Eaton (2020).

Thus, the OGDPs are important open public databases which allow governmental and external actors to innovate and add public value, that is, to generate value to society (Bonina \& Eaton, 2020; Cordella \& Paletti, 2019).

\subsection{Public value}

Before addressing the phenomenon of public value generation through services developed with open public data (Cordella \& Paletti, 2019), it is important to understand the meaning of public value, which was a concept conceived in the United States during the 1990s, more precisely in executive 
education programs for public managers, which were offered by the John Fitzgerald Kennedy School of Government, at Harvard University, which had several professors, including Mark Moore (Alford \& O'Flynn, 2009).

Mark Moore (1994) was a pioneer in terms of scientific production on the concept of public value, since the first publication of an academic study on the subject is attributed to him, whose arguments for his work focus on the main difference between public and private organizations: their purposes.

According to Moore (1994), all strategic efforts of a private company seek, in some way, to generate economic value for its shareholders. In public organizations, however, the presence of shareholders does not exist, but that of citizens who are members of a society to which the government needs to strive to generate public value, which can be understood as the result of government action that meets the real needs of society, considering, for this, the collective expectations of citizens (Moore, 1994).

The value that the government generates to society through its actions can be observed through the individual assessments of citizens, since, although the assessment of a citizen allows to identify more clearly the private value that public action generates, also it is possible to verify components of this performance that may be able to add value to society or to a considerable part of the people that comprise it. For example, the good performance of services provided by public schools adds individual value to students in these schools; however, it also generates public value for improving the population's formal education and for all the collective benefits that this provides (Hartley, Alford, Knies, \& Douglas, 2017).

Given its growing importance, the concept of public value has been investigated in all possible situations in which the State acts, such as in the regulation of economic agents, inspection of productive activities, elaboration of legal norms, and provision of public services (Hartley et al., 2017; Panagiotopoulos, Klievink, \& Cordella, 2019; Twizeyimana \& Andersson, 2019). However, the literature still lacks a better understanding of this phenomenon through digital services and technologies created through open public data (Cordella \& Paletti, 2019).

\subsubsection{Public value through digital services and technologies created with open government data}

Data opened by a public agency can be used by other public organizations to develop services to the population. In addition, private companies and citizens can use open public data to create services for society. This 
generates the understanding that the public value generated through services based on open government Data can happen through direct government action or through external actors to the public administration (Cordella \& Paletti, 2019).

For example, providing anonymous public data on medical treatment given to British patients made it possible for outsiders to the government, such as universities, pharmaceutical companies, and startups, to develop and improve therapies and drugs, as well as applications which helped the government to better assist users of health services (Kallinikos \& Tempini, 2014). Another frequently cited example is the British transport application Citymapper, developed by a private organization with open government data to provide a service capable of generating value to society (Bonina \& Eaton, 2020).

However, even though many websites and applications based on open public data are created by actors outside the public administration, the government, as the platform owner, influences the generation of public value by encouraging that data, made available by public organizations, are secure, of quality, of easy interoperability and useful to external developers (Cordella \& Paletti, 2019).

Thus, the generation of public value through applications, websites, and platforms developed with open public data is the result of a process that involves different governmental and private actors, each with its importance in building value for society (Bonina \& Eaton, 2020; Cordella \& Paletti, 2019).

Finally, the public value generated through digital technologies, with open public data, can be observed in several ways, such as improvements in the performance of public services (Bonina \& Eaton, 2020), in the expansion of transparency of government actions, and in the engagement of citizens in social control (Cordella \& Paletti, 2019).

\subsection{Social control}

The theoretical approach to social control focuses on a more active and participatory relationship between the State and the society, from which various elements emerge, constituted by public action and social concerns (Andrade \& Andrade, 2019).

There is a consensus that the citizen's presence in the democratic process should not be limited to the selection of political representatives, since society can participate, for example, in the preparation of public budgets, public hearings, popular councils, and the inspection of acts and public 
accounts. Furthermore, the advance in the transparency of public acts and in the opening of government data is expanding and facilitating this social control (Bitencourt \& Reck, 2016).

Social control can be defined as the engagement of citizens to monitor and supervise actions and public policies. Citizen action in social control collaborates to verify whether public acts are taking place in favor of the collective interest, as well as to identify whether they are efficient and honest (Sabioni et al., 2016).

\subsubsection{Social control in Brazil through digital technologies}

In Brazil, the exercise of citizenship through control and social participation was enhanced in the mid-1980s, after a long dictatorial period. The resumption of democracy in Brazil and the promulgation of the Federal Constitution of 1988, which granted more powers to citizens, such as the right to file complaints directly to the Court of Auditors and to formally complain about irregularities that occurred during the provision of public services, stimulated and expanded social control in the country (Andrade \& Andrade, 2019).

After the Brazilian dictatorial period, several initiatives took place to expand participation and social control in Brazil, such as the 1986 national health conference, which resulted in the recommendation of the reformulation of the National Health Council to include actors of civil society in its composition, culminating on December 28, 1990, in the publication of Law no. 8142 , which instituted instances of participation and Social control at conferences and Health Councils (Nunes \& Cançado, 2020).

Subsequently, in 1995, the Brazilian public administration underwent a management reform with the main aim of eradicating bureaucratic dysfunctions and, consequently, making government action faster, more efficient, and focused on results, generating less formalism and a more "a posteriori" control. Furthermore, the managerial reform of the State, led by the minister of Economy Bresser-Pereira, aimed to increase participation and social control in Brazil, creating a managerial and societal public administration at the same time (Bataglia \& Farranha, 2021).

This contributed to the generation of various popular consultation tools, which, associated with the Brazilian electronic government's advance, contributed to increase the transparency of public acts and to the opening of government data in Brazil. Like many countries, Brazil has adopted the concept of open government (Bataglia \& Farranha, 2021; Salomão, 2017), which 
can be understood as the intensive use of digital technologies to facilitate, encourage and expand government transparency, openness, and sharing of public data, access to public information, and social participation and control (Nam, 2012; Tai, 2021).

In Brazil, the advance of transparency of public acts and the opening of government data in the digital scope have been collaborating to increase social control. However, overall, the engagement of Brazilian citizens in social control is still quite low, which occurs mainly for cultural reasons, technical inability, low digital inclusion, and for the effort that needs to be used to access and understand the government data (Andrade \& Andrade, 2019; Sabioni et al., 2016).

For example, the study conducted by Gomes (2018) in the city of Sete Lagoas, Minas Gerais, found that $95 \%$ of the interviewed citizens use the internet regularly but do not access the city's transparency portal. In other words, only $5 \%$ of the survey participants monitored and inspected the municipality's public accounts, which was mainly explained by the lack of habit, technical capacity, and time to carry out the monitoring and inspection effort of public accounts.

On the other hand, government efforts are being made to encourage and facilitate the engagement of social control in Brazil, as governments of all spheres are increasingly seeking to encourage democratic participation and social control through popular councils, public hearings, and various other mechanisms (Andrade \& Andrade, 2019).

In addition, actors outside the public administration are developing digital technologies to facilitate the monitoring and inspection of public acts and accounts, such as the Monitora, Brasil! and the Super Citizen, as well as the websites Cuidando do Meu Bairro, Radar Parlamentar, Repasse, Gastos Públicos e Operação Serenata de Amor (Brazil, 2021g).

Thus, although the engagement of Brazilian citizens is still low, this tends to increase with the advance of transparency in public acts (Andrade \& Andrade, 2019; Sabioni et al., 2016) and with the development of digital technologies that encourage and facilitate social control (Brazil, 2021g).

\section{METHODOLOGY}

This study sought, through a qualitative approach with a descriptive focus, to understand the public value that the Operation Serenata de Amor website can create for society. 
To achieve the aim of the study, the single case study method was adopted. According to Yin (2017), the application of the single case study is adequate to understand, in greater depth, phenomena that occur in a context.

Data collection took place through evidence available on the internet, such as citizens' comments on social media and records of initiatives on the Operação Serenata de Amor website. The collection took place from January 2019 to January 2021, with 331 posts from citizens on the Operation Serenata de Amor website on Facebook, which has 68.613 followers. In addition, 948 comments were collected from citizens on the site's Twitter profile page, which has 40.800 followers.

For the data analysis process, the content analysis method was used, which is a systematic way of investigating, organizing, and reducing textual content, which facilitates the understanding of the meaning of individuals' opinions in the contexts in which they were created (Creswell \& Poth, 2018; Leavy, 2017).

\subsection{The Operação Serenata de Amor website case}

The Operação Serenata de Amor website is the result of a technology project that sought to use artificial intelligence (AI) to audit public accounts of federal deputies and Brazilian senators, with the aim of assisting in social control. The project's developer was the data scientist Irio Musskopf. By sharing the idea with friends, Musskopf was able to provide the necessary resources to develop the website in 2016, which currently has a team of 10 people and more than 600 volunteers (Operação Serenata de Amor, 2021a).

In an interview to Jornal Correio, Mario Sérgio, technical leader of Operação Serenata de Amor, informed that the name of the site was inspired by the Toblerone case, which refers to the episode in which the Swedish population demanded the resignation of a minister of the country because of the purchase of a Toblerone chocolate bar and other personal expenses with the corporate card (Borges, 2019).

The Operação Serenata de Amor website, developed with open public data, allows any citizen to monitor the use of the Quota for Exercising Parliamentary Activities (Cota para o Exercício da Atividade Parlamentar Ceap), which is intended for federal deputies and Brazilian senators to receive reimbursement for various expenses, such as food, transportation, accommodation and educational and cultural activities (Brazil, 2021h).

The site developed an AI called Rosie, which analyzes the expenses reimbursed by deputies and senators, identifying suspicions and encouraging 
social control of public expenses (Operação Serenata de Amor, 2021b). The site employs machine learning techniques to locate atypical reimbursements in CEAP, posting them on social media so that citizens can view, investigate, question, and even report them (Brazil, 2021h).

Besides, so that citizens are able to understand the information generated by Rosie, the site created Jarbas, a software that facilitates the verification of information regarding the reimbursement of expenses for parliamentarians (Operação Serenata de Amor, 2021b).

\section{ANALYSIS AND DISCUSSION OF RESULTS}

This section analyzes, through data collected on the internet, the initiatives and the results achieved by the Operação Serenata de Amor website, with the aim of discussing the value it can add to society.

The Operação Serenata de Amor website gets many positive comments from citizens on their official Facebook page (Operação Serenata de Amor, 2021c) and Twitter profile (Operação Serenata de Amor, 2021d), some recognizing the importance to society:

An effort like this should be known by everyone [...]. It should be discussed everywhere, in bars and restaurants. Congratulations on your dedication. And hopefully, the day will come when I will see the common citizens interested in public management.

Information and transparency are all we need.

Congratulations to the Serenade! Incredible project and still little known but which is already of great importance to our society!

On its official page on Facebook and Twitter, the Operação Serenata de Amor website facilitates and encourages social control over the expenses of federal deputies and senators, helping citizens to be interested in monitoring the expenses of parliamentarians (Operação Serenata de Amor, 2021c, 2021d). The website's initiative shows the public value that it generates, especially because of the negative history of citizen engagement in Brazilian social control (Sabioni et al., 2016).

On several occasions, the Operação Serenata de Amor website, through Rosie, its AI, identified suspicious expenses and stimulated citizens' investigation. For example, in 2019, Rosie identified unusual spending by a federal deputy. After the disclosure of the information on the website's Facebook 
page, several citizens questioned the deputy through his official Facebook account, as can be seen below:

Deputy, by the barcode of the tax coupon that you asked for a refund, you bought this gourmet chocolate there... What is the need for this chocolate for your activity as a federal deputy?

Deputy, buying chocolate with people's money????

What's up, Deputy? Will you explain this? Why didn't you buy it with your salary?

Deputy, let's spend the public money sparingly... we've done our best to pay taxes to pay your perks.

Deputy, if you want to eat chocolate, pay with the money from your hefty salary as a deputy that we pay you. Eating chocolate is normal (although millions of Brazilians can't even do that), but a $30 \mathrm{BRL}$ chocolate paid with public money is not moral.

In addition to questioning parliamentarians with data collected by Rosie, citizens use Jarbas to better understand deputies' expenses, which demonstrates greater citizen engagement, as they strive to analyze and interpret the legality of the expense before questioning the parliamentarian:

The deputy spends very high amounts and lives extremely comfortable with the people's money. In this case, he bought two meals (extremely expensive), which in my opinion is already irregular, since the deputy cannot buy meals for companions. The deputy also rented two cars in a single day, $03 / 20 / 2019$. On: link to the analysis made by Jarbas. I would like to know if the rent of two vehicles is also irregular. But, regardlessly, it is very sad to see the disrespect for public money. The deputy rents unnecessarily expensive cars.

In a similar situation, there is, again, a greater effort by the citizen to analyze and interpret the legality of the expenditure before questioning the parliamentarian:

What caught my attention is that on the same day he had another refund, on the same day, and from the same restaurant. As noted above, the first note has no consumption breakdown and the second note, despite being well erased, seems to have an expenditure breakdown. Another thing that caught my attention was the time of each 
note, the first one at 10:41 pm and the second one at 10:43 pm... strange, to say the least. The second note has a code that sends the first one, which suggests that the second one is correct, as it has the items consumed, including the tip. This second note also contains a discount, which differs from the value of the first, VAT was not paid, according to the second receipt. The two refund requests are for the same meal, the same expense. The congressman is asking for a double refund. [...] deputy, could you explain the two requests for reimbursement? Also, inform if expenses abroad are subject to reimbursement and if your agenda (as a parliamentarian) includes the date.

Thus, it is possible to understand that the Operação Serenata de Amor website generates public value by contributing to a change in Brazilians' habits regarding social control, as it facilitates and awakens the interest of citizens in researching and analyzing in more detail the apparent anomalies found in the expenses of parliamentarians. This is essential, since a considerable part of the low index of social control in Brazil is explained by the lack of habit and time of citizens, as well as by the effort that needs to be made to inspect public accounts (Andrade \& Andrade, 2019).

It was also possible to notice that, in addition to questioning parliamentarians directly, citizens analyze the data disclosed by the website and file formal complaints with the control bodies: "I asked the chamber's ombudsman about a request by deputy XXX on July 29, but so far they haven't answered me. When you receive it, I will show you guys".

Site administrators, when they find suspicious expenses, also report to the control bodies. So far, they have already denounced 629 suspicious refunds, which involved 216 parliamentarians and amounts in excess of 370 thousand reais (Operação Serenata de Amor, 2021b).

Among the atypical spendings, the expense of $\mathrm{R} \$ 6.205 .00$ for a single meal of a parliamentary has already been denounced, as well as $\mathrm{R} \$ 6.000 .00$ spent by a parliamentary with gasoline over a period of 30 days (Operation Serenata de Amor, 2021b). The site has already detected that a federal deputy had 13 meals in a single day. After the website filed the complaint, the deputy claimed that his office had made a mistake. The deputy's chief of staff informed that the refunded amount was given back, as well as acknowledged that the expense was undue by explaining that the deputy's driver made a mistake when asking for reimbursement of this expense, which was related to the lunch of a group of elderly people who visited the Chamber of Deputies (Luiz, 2016). 
The site has also identified that a federal deputy spent public money on alcoholic beverages, which is illegal. After the complaint, the representative's office apologized for the mistake and returned the money. The crossing of public data made available by the Chamber of Deputies and the Federal Revenue also allowed identifying that a deputy had expenses in very distant cities in a short period of time. This deputy claimed that his staff made a mistake and returned the money. Furthermore, and in seven other cases reported, they have recognized the mistake and returned the value reimbursed by the House of Representatives (Mendonça, 2017).

Thus, the evidence found shows the importance of the Operação Serenata de Amor website for social control, either directly or through the positive influence that the initiatives of the website carry on citizen engagement, which is a generating factor of public value for stimulating and facilitating the advancement of social control in Brazil.

In addition, the site generates public value when it imparts knowledge that enhances the ability of a citizen to exercise social control. For example, in 2019, one of the website's collaborators published a text explaining details about the rules of the CEAP (Operation Serenata de Amor, 2021e), encouraging citizens to acquire knowledge about it: "Very good these explanations...but, then, how do most deputies spend this "quota" on air tickets for their advisors!?? check out the expenses of former senator XXX!!!! look there...".

The website's collaborators also seek to interact with citizens to resolve their doubts about CEAP and other issues inherent to the theme of social control, as it is shown in the answer bellow: "Answering your question: CEAP does not specify that the purchase of airline tickets is exclusive to the congressman, therefore, he can buy airline tickets for assistants".

The site's developers also encourage citizen participation in lectures on transparency and social control of public spending. In 2020 and 2021, they gave lectures on various subjects related to the theme, such as the live in the Civic Innovation Ambassadors Program, which sought to explain the functioning of control bodies, such as courts of accounts, controllerships, and public defenders (Operation Serenata de Amor, 2021c).

The fact that the website seeks to empower citizens to carry out social control in a suitable manner is fundamental for the advancement of social control in the country, given that the low engagement of citizens is also influenced by the lack of technical capacity that many people have to understand and assess whether public acts and expenditures are taking place within the principles of legality and morality (Andrade \& Andrade, 2019; Sabioni et al., 2016). 
Thus, the Operação Serenata de Amor website, based on open public data, adds value to society by carrying out, facilitating, and encouraging social control, as well as generating public value by transmitting information that corroborates to expand the technical capacity of citizens to exercise social control.

\section{CONCLUSION}

This study aimed to understand what kind of public value the Operação Serenata de Amor website can generate for society based on open government data.

The results showed that citizens evaluate the initiatives of the Operação Serenata de Amor website as fundamental for society. It was also detected that the website facilitates and encourages citizen engagement in social control by influencing the examination of expenses of parliamentarians and the questioning and denouncing of suspicious spending to control bodies. Employees of the site also make complaints when they find suspicious expenses. Furthermore, the site seeks to transmit knowledge that can improve the technical capacity of citizens to exercise social control.

In other words, this study found evidence that the Operação Serenata de Amor website generates public value by carrying out, facilitating, and encouraging social control, which has its importance increased, due to the history of low engagement of Brazilians in social control (Sabioni et al., 2016). It was also identified that the site adds value to society by providing citizens with information that can expand their skills to exercise social control, which is important, given the understanding that Brazilian citizens, as a rule, still have low technical capacity to exercise social control of actions and public accounts (Andrade \& Andrade, 2019).

Thus, the results of this work contribute to the understanding that the opening of public data to actors outside the government can be a factor of fundamental importance for society, specifically for the development of digital technologies that support the engagement of citizens in social control, which is translated into value for society, as advocated by Cordella and Paletti (2019).

However, the study was limited to collecting data available on the internet, which creates the opportunity for future researchers, who will be able, through interviews or questionnaires, to collect citizens' evaluations about the digital technologies developed for contributing to the advancement of social control in Brazil. Finally, research can also be carried out that seeks to understand the barriers that innovators outside the government face to add 
public value through digital technologies that help in social control, and consequently, in the issue of generating value for society.

\section{VALOR PÚBLICO VIA TECNOLOGIAS DESENVOLVIDAS COM DADOS GOVERNAMENTAIS ABERTOS: O CASO OPERAÇÃO SERENATA DE AMOR}

\section{RESUMO}

Objetivo: Compreender que tipo de valor público o site Operação Serenata de Amor, baseado em dados governamentais abertos, pode gerar para a sociedade.

Originalidade/valor: Pesquisadores estão investigando a geração de valor público por meio de serviços públicos transformados digitalmente, ou seja, valor público criado diretamente pelo governo. No entanto, a literatura ainda carece da melhor compreensão desse fenômeno por intermédio de tecnologias digitais, com dados públicos abertos, desenvolvidas por atores externos ao governo, tais como o site Operação Serenata de Amor. Design/metodologia/abordagem: O estudo adotou a abordagem qualitativa para entender e descrever o valor público gerado pelo site Operação Serenata de Amor. Os dados foram coletados por meio de comentários dos cidadãos acerca das iniciativas do site em mídias sociais e em matérias publicadas na internet. Já a análise de dados ocorreu por intermédio da análise de conteúdo.

Resultados: O site Operação Serenata de Amor gerou valor público por realizar, facilitar e estimular o controle social. Também foi identificado que o site agregou valor à sociedade por ampliar a capacidade de um cidadão exercer o controle social. Entretanto, este trabalho se limitou a analisar dados coletados na internet. Em futuros estudos, pesquisadores podem coletar dados por meio de entrevistas com os cidadãos para entender, com mais profundidade, o valor público gerado pelo site.

\section{PALAVRAS-CHAVE}

Transformação digital governamental. Governo aberto. Dados públicos abertos. Valor público. Controle social. 


\section{REFERENCES}

Alford, J., \& O’Flynn, J. (2009). Making sense of public value: Concepts, critiques and emergent meanings. International Journal of Public Administration, 32, 171-191. doi:10.1080/01900690902732731

Andrade, A. C. F., Filho, \& Andrade, A. M. (2019). Controle social: Ferramenta para o exercício da cidadania/social. Id on-line Revista Multidisciplinar e de Psicologia, 13 (44), 945-961. doi:10.14295/idonline.v13i44.1668

Bataglia, M. B., \& Farranha, A. C. (2021). Controle social e acesso à informação: $O$ papel da transparência passiva no enfrentamento à corrupção. Interfaces Científicas, 6(3), 27-42. doi:10.17564/2316-381X.2018 v6n3p27-42

Bitencourt, C. M., \& Reck, J. R. (2016). Controle da transparência na contratação pública no Brasil: $\mathrm{O}$ acesso à informação como forma de viabilizar o controle social da administração pública. Revista do Direito, 2(49), 96-115. doi:10.17058/rdunisc.v2i49.7892

Bonina, C., \& Eaton, B. (2020). Cultivating open government data platform ecosystems through governance: Lessons from Buenos Aires, Mexico City and Montevideo. Government Information Quarterly, 37(3), 1-15. doi:10.10 16/j.giq.2020.101479

Borges, T. (2019). Conheça a Operação Serenata de Amor, que criou robô para monitorar gastos de parlamentares. Correio. Retrieved from https:// www.correio24horas.com.br/noticia/nid/conheca-a-operacao-serenatade-amor-que-criou-robo-para-monitorar-gastos-de-parlamentares/? fbclid=IwAR093-Ry9DvuuyeEV3s9AVAhhp7jrhL6VKeNlxCYKOHB 29wZ_KXAWM_NLb4

Brasil (2021a). Governo como plataforma: Pesquisa API para mercado. Retrieved from https://www.gov.br/governodigital/pt-br/governanca-dedados/governo-como-plataforma Brasil (2021b). Portal Brasileiro de Dados Abertos: Desenvolvimento do portal. Retrieved from https://dados.gov.br/ pagina/dev

Brasil (2021c). Lei n. 13.709, de 14 de agosto de 2018. Retrieved from http:// www.planalto.gov.br/ccivil_03/_ato2015-2018/2018/lei/113709.htm

Brasil (2021d). Portal Brasileiro de Dados Abertos: Conjunto de dados. Retrieved from https://dados.gov.br/dataset

Brasil (2021e). Portal Brasileiro de Dados Abertos: Organizações. Retrieved from https://dados.gov.br/organization 
Brasil (2021f). Portal Brasileiro de Dados Abertos: Sobre o dados.gov.br. Retrieved from https://dados.gov.br/pagina/sobre

Brasil (2021g). Portal Brasileiro de Dados Abertos: Aplicativos. Retrieved from https://dados.gov.br/aplicativos

Brasil (2021h). Portal Brasileiro de Dados Abertos: Operação Serenata de Amor. Retrieved from https://dados.gov.br/aplicativo/operacao-serenatade-amor

Brown, A., Fishenden, J., Thompson, M., \& Venters, W. (2017). Appraising the impact and role of platform models and government as a platform (GaaP) in UK government public service reform: Towards a Platform Assessment Framework (PAF). Government Information Quarterly, 34(2), 167-182. doi:10.1016/j.giq.2017.03.003

Cordella, A., \& Paletti, A. (2019). Government as a platform, orchestration, and public value creation: The Italian case. Government Information Quarterly, 36(4), 1-15. doi:10.1016/j.giq.2019.101409

Creswell, J. W., \& Poth, C. N. (2018). Qualitative inquiry and research design: Choosing among five approaches (4th ed.). Thousand Oaks: Sage.

Croitor, E., \& Benlian, A. (2019). Perceived input control on online platforms from the application developer perspective: Conceptualisation and scale development. Journal of decision systems, 28(1), 19-40. doi:10.1080/ 12460125.2019.1616977

Curtis, S. (2019). Digital transformation - The silver bullet to public service improvement? Public Money \& Management, 39(5), 322-324. doi:10.1080/ 09540962.2019.1611233

Danneels, L., Viaene, S., \& Bergh, J. V. D. (2017). Open data platforms: Discussing alternative knowledge epistemologies. Government Information Quarterly, 34(3), 365-378. doi:10.1016/j.giq.2017.08.007

Datta, P., Walker, L., \& Amarilli, F. (2020). Digital transformation: Learning from Italy's public administration. Journal of Information Technology Teaching Cases, 10(2), 54-71. doi:10.1177/2043886920910437

De Reuver, M., Sørensen, C., \& Basole, R. C. (2018). The digital platform: A research agenda. Journal of Information Technology, 33(2), 124-135. doi:10.1057/s41265-016-0033-3

Goede, M. (2019). E-Estonia: The e-government cases of Estonia, Singapore, and Curaçao. Archives of Business Research, 7(2), 216-227. doi:10.14738/abr. 72.6174 
Gomes, C. C. A. (2018). O controle social sobre os atos do Poder Executivo na administração pública municipal de Sete Lagoas: Uma visão a partir da população setelagoana (Monografia, Universidade Federal de São João del-Rei, São João del-Rei, MG, Brasil).

Hänninen, M., Smedlund, A., \& Mitronen, L. (2018). Digitalization in retailing: Multi-sided platforms as drivers of industry transformation. Baltic Journal of Management, 13(2), 152-168. doi:10.1108/BJM-04-2017-0109

Hartley, J., Alford, J., Knies, E., \& Douglas, S. (2017). Towards an empirical research agenda for public value theory. Public Management Review, 19(5), 670-685. doi:10.1080/14719037.2016.1192166

Hukal, P., Henfridsson, O., Shaikh, M., \& Parker, G. (2020). Platform signaling for generating platform content. MIS Quarterly, 44(3), 1177-1205.

Kallinikos, J., \& Tempini, N. (2014). Patient data as medical facts: Social media practices as a foundation for medical knowledge creation. Information Systems Research, 25(4), 817-833. doi:10.1287/isre.2014.0544

Koskinen, K., Bonina, C., \& Eaton, B. (2019). Digital platforms in the global south: Foundations and research agenda. In Nielsen P. \& Kimaro H. C. (Eds.), Information and communication technologies for development. Strengthening Southern-driven cooperation as a catalyst for ICT4D (pp. 319-330). Basingstoke: Springer. doi:10.1007/978-3-030-18400-1_26

Leavy, P. (2017). Research design: Quantitative, qualitative, mixed methods, artsbased, and community-based participatory research approaches. New York: The Guilford Press.

Lee, J., Kim, B. J., Park, S. J., Park, S., \& Oh, K. (2018). Proposing a valuebased digital government model: Toward broadening sustainability and public participation. Sustainability, 10(9), 1-13. doi:10.3390/su10093078

Leoni, G., \& Parker, L. D. (2019). Governance and control of sharing economy platforms: Hosting on Airbnb. The British Accounting Review, 51(6), 1-22. doi:10.1016/j.bar.2018.12.001

Luiz, G. (2016). Após ser flagrado por app, deputado devolve à Câmara R\$ 727 por 13 refeições no mesmo dia. G1. Retrieved from https://g1. globo.com/distrito-federal/noticia/apos-ser-flagrado-por-app-deputadodevolve-a-camara-r-727-por-13-refeicoes-no-mesmo-dia.ghtml

Mendonça, H. (2017). Rosie, a robô que detecta quando deputados usam mal o dinheiro público. El País. Retrieved from https://brasil.elpais.com/ brasil/2017/01/23/politica/1485199109_260961.html?id_externo_rsoc= TW_BR_CM 
Mergel, I., Edelmann, N., \& Haug, N. (2019). Defining digital transformation: Results from expert interviews. Government Information Quarterly, 36(4), 1-16. doi:10.1016/j.giq.2019.06.002

Michener, G., Contreras, E., \& Niskier, I. (2018). Da opacidade à transparência? Avaliando a Lei de Acesso à Informação no Brasil cinco anos depois. Revista de Administração Pública, 52 (4), 610-629. doi:10.1590/0034-7612 20170289

Moore, M. H. (1994). Public value as the focus of strategy. Australian Journal of Public Administration, 53(3), 296-303. doi:10.1111/j.1467-8500.1994.tb 01467.x

Nam, T. (2012). Citizens' attituds toward Open Government and Government 2.0. International Review of Administrative Sciences, 78(2), 346-369. doi:10.1177/0020852312438783

Nielsen, M. M., \& Jordanoski, Z. (2020, June). Digital transformation, governance and coordination models: A comparative study of Australia, Denmark and the Republic of Korea. Annual International Conference on Digital Government Research, Seoul, Republic of Korea, 21. doi:10.1145/3396956. 3396987

Nunes, C. O., \& Cançado, A. C. (2020). Desenvolvimento local e controle social: Notas sobre os conselhos gestores de políticas públicas em saúde no Brasil e no Tocantins. Revista Humanidades e Inovação, 7(14), 145-155.

Operação Serenata de Amor (2021a). Sobre o projeto. Retrieved from https:// serenata.ai/about

Operação Serenata de Amor (2021b). Inteligência artificial para o controle da administração pública. Retrieved from https://serenata.ai

Operação Serenata de Amor (2021c). Página oficial do site Operação Serenata de Amor no Facebook. Retrieved from https://www.facebook.com/operacao SerenataDeAmor

Operação Serenata de Amor (2021d). Rosie da Serenata. Retrieved from https://twitter.com/RosieDaSerenata? source=post_page-

Operação Serenata de Amor (2021e). (Quase) tudo o que você precisa saber sobre a CEAP. Retrieved from https://medium.com/serenata/quase-tudoo-que-voc\%C3\%AA-precisa-saber-sobre-a-ceap-676b900c3dac

O'Reilly, T. (2011). Government as a platform. Innovations: Technology, Governance, Globalization, 6(1), 13-40. doi:10.1162/INOV_a_00056

Panagiotopoulos, P., Klievink, B., \& Cordella, A. (2019). Public value creation in digital government. Government Information Quarterly, 36(4), 1-8. doi:10.1016/j.giq.2019.101421 
Petrini, M., Freitas, C. S., \& Silveira, L. M. (2017). Uma proposta para uma tipologia de economia de compartilhamento. Revista de Administração Mackenzie, 18(5), 39-62. doi:10.1590/1984-9260919

Sabioni, M., Ferreira, M. A. M., Braga, M. J., \& Almeida, F. M. (2016). Contextos (in)adequados para o engajamento cidadão no controle social. Revista de Administração Pública, 50(3), 477-500. doi:10.1590/0034-7612153518

Salomão, N. A., Neto (2017). Rumo a um governo aberto: Lições arquivísticas da Open Government Partnership para Brasil e México. Legajos Boletín del Archivo General de la Nación, 13(4), 83-110. doi:10.31911/bagn.2017.8.13.55

Scupola, A. (2018). Digital transformation of public administration services in Denmark: A process tracing case study. Nordic and Baltic Journal of Information and Communications Technologies, 1(1), 261-284. doi:10.13052/ nbjict1902-097X.2018.014

Senyo, P. K., Effah, J., \& Osabutey, E. L. C. (2021). Digital platformisation as public sector transformation strategy: A case of Ghana's paperless port. Technological Forecasting \& Social Change, 162, 1-13. doi:10.1016/j.techfore. 2020.120387

Tai, K.-T. (2021). Open government research over a decade: A systematic review. Government Information Quarterly, 38(2), 1-15. doi:10.1016/j.giq. 2021.101566

Täuscher, K., \& Laudien, S. M. (2018). Understanding platform business models: A mixed methods study of marketplaces. European Management Journal, 36(3), 319-329. doi:10.1016/j.emj.2017.06.005

Tiwana, A. (2014). Platform ecosystems: Aligning architecture, governance, and strategy. Burlington: Morgan Kaufmann.

Tiwana, A. (2015). Evolutionary competition in platform ecosystems. Information Systems Research, 26(2), 266-281. doi:10.1287/isre.2015.0573

Tiwana, A. (2018). Platform synergy: Architectural origins and competitive consequences. Information Systems Research, 29(4), 829-848. doi:10.1287/ isre.2017.0739

Twizeyimana, J. D., \& Andersson, A. (2019). The public value of E-Government - A literature review. Government Information Quarterly, 36(2), 167-178. doi:10.1016/j.giq.2019.01.001

Yin, R. K. (2017). Case study research and applications: Design and methods. Thousand Oaks: Sage. 


\section{AUTHOR NOTES}

Eduardo D. Coutinho, master from the Graduate Program in Business Administration and Development, Estacio de Sá University; Angilberto S. Freitas, Ph.D. from the Graduate Program in Business Administration, Pontifical Catholic University of Rio de Janeiro (PUC-Rio). Eduardo D. Coutinho is now a Ph.D. student at the Graduate Program in Business Administration of University of Grande Rio (Unigranrio); Angilberto S. Freitas is now a professor at the Department of Production Engineering of West Zone University Center (Uezo).

Correspondence concerning this article should be addressed to Eduardo D. Coutinho, Rua Professor José de Souza Herdy, 1160, Jardim Vinte e Cinco de Agosto, Duque de Caxias, Rio de Janeiro, Brazil, CEP 25071-202.

E-mail: ediascoutinho@yahoo.com.br

\section{EDITORIAL BOARD}

Editor-in-chief

Gilberto Perez

Associate editor

Rodrigo Baroni de Carvalho

Technical support

Vitória Batista Santos Silva

\section{EDITORIAL PRODUCTION}

Publishing coordination

Jéssica Dametta

Language editor

Daniel de Almeida Leão

Layout designer

Emap

Graphic designer

Libro 